\title{
PEMANFAATAN METODE FUZZY UNTUK BUDIDAYA IKAN TOMBRO BEBRASIS IOT (INTERNET OF THING)
}

\author{
Dony Ariefianto, Agung Panji Sasmito, Abdul Wahid \\ Program Studi Teknik Informatika S1, Fakultas Teknologi Industri \\ Institut Teknologi Nasional Malang, Jalan Raya Karanglo km 2 Malang, Indonesia \\ 1718107@scholar.itn.ac.id
}

\begin{abstract}
ABSTRAK
Ikan tombro merupakan salah satu jenis ikan tawar yang banyak diminati karena memiliki rasa yang gurih dan enak serta berprotein yang cukup tinggi. Tujuan Dalam melakukan pengelolaan biasanya pembudidaya tersebut melakukan pengecekan kolam secara terus menerus hal tersebut memakan waktu untuk melakukan pemantauan. Penelitian ini merupakan solusi untuk mempermudah dengan sistem monitoring budidaya ikan tombro yang bisa diakses kapanpun dimanapun. Dengan implementasi metode fuzzy Kebutuhan produk skripsiyang dikembangkanmencakup yaitu beberapa sensor yang dapat membantu melakukan monitoring budidaya ikan tombro yang lebih efektif dengan menggunakan arduino atau mikrokontroller.Hasil penelitian ini adalah produk berupa monitoring budidaya ikan tombro dengan menggukan sensor $p H$ dan Turbidity yang diharapkan dapat membantu pembudidaya dapat melakukan pengelolaan secara maksimal. Sistem monitoring ini dapat mempermudah pemantauan budidaya ikan tombro dengan memanfaatkan sensor turbidity $\mathrm{pH}$ dan suhu. Berdasarkan pengujian bebrapa sensor menunjukan bahwa hasil dari monitoring budidaya ikan tombro ini berjalan dengan baik. berdasarkan pengujian terhadap fitur pompa otomatis menggunakan metode fuzzy hasil terhitung akurasi yang cukup baik. berdasarkan pengujian pengguna diketahui mayoritas penggunaa dapat memeahami dan menggunakan fitur pada monitoring budidaya ikan tombro. berdasarkan penelitian disimpulkan bahwa dapat mempermudah untuk pembudidaya dalam pengawasan kolam serta tidak membutuhkan waktu yang lama untuk memantau kolam tanpa harus repotmelihat kolamnya
\end{abstract}

Kata kunci : Arduino, Fuzzy, website, Monitoring

\section{PENDAHULUAN}

Ikan tombro merupakan ikan segar. Karena rasanya yang enak dan kandungan protein yang tinggi, Argowindo (2013) merupakan ikan segar yang banyak diminati. Kisaran suhu hidup ikan adalah 2430 derajat Celcius dan $\mathrm{pH}$ 6-7. Untuk mendapatkan efek yang maksimal, petugas pemeliharaan harus menggunakan air yang tenang atau tidak terlalu deras, dan harus melakukan sirkulasi air yang baik secara teratur. Pemeliharaan ini bisa dilakukan selama 3-4 bulan.

Untuk memaksimalkan cara pemeliharaan ikan ini, pakan juga menjadi prioritas penting. Kesehatan ikan dapat dilihat dari nafsu makan ikan, stres ini dapat menyebabkan beberapa penyakit pada ikan, seperti jamur, eritema, gatal-gatal dan penyakit lainnya, beberapa diantaranya dapat menyebabkan nafsu makan ikan menurun, Paktanidigital.com (2017).

Dalam melakukan pengelolaan biasanya pembudidaya tersebut melakukan pengecekan kolam secara terus menerus hal tersebut memakan waktu untuk melakukan pemantauan. Untuk mengatasi hal tersebut bisa menggunakan beberapa sensor yang dapat membantu melakukan monitoring budidaya ikan tombro yang lebih efektif dengan menggunakan arduino atau mikrokontroller. Pertanianku.com (2016)

Berdasarkan paparan tersebut diatas diketahui bahwa sejauh ini pembudidayaan yang dilakukan adalah secara manual. Cara tersebut sangat tidak efektif dan praktis, perlu banyak waktu untuk melakukan satu pekerjaan saja. Peneliti menggagas adanya monitoring budidaya ikan tombro dengan menggukan sensor $p H$ dan Turbidity yang diharapkan dapat membantu pembudidaya dapat melakukan pengelolaan secara maksimal.

\section{TINJAUAN PUSTAKA}

Kadir (2019) terkait penelitian yang berjudul Mobile IOT (INTERNET OF THINGS) Untuk Pemantauan Kualitas Air Habitat Ikan Hias Pada Akuarium Menggunakan Metode Logika Fuzzy Metode ini merupakan metode logika fuzzy yang sesuai untuk Kecepatan pompa air di filter. pompa air. Diharapkan melalui sistem ini, pemilik akuarium dapat memantau keadaan kualitas air dengan lebih baik. Pengujian sistem menggunakan sensor ds18b20 untuk mengukur suhu air, sensor turbiditas untuk mengukur kekeruhan air, sensor $\mathrm{pH}$ untuk mengukur keasaman air dan sensor infra merah untuk deteksi umpan. Hal ini mendukung manfaat penggunaan sensor suhu, ds18b20, dan sensor kekeruhan air.

Afifuddin (2019) Terkait penelitian yang berjudul Penerapan Metode Fuzzy Untuk monitor Penggunaan Air Rumah Tangga Berbasis Arduino Dalam penelitian ini penulis memberikan solusi dengan sistem monitor penggunaan air yang bisa di akses kapanpun dan dimanapun. pengolahan data ini Yang Akan menentukan terbuka tutupnya kran pengisian tandon, untuk menetukan terbuka atau tertutupnya kran pengisian tandon ada beberapa 
kondisi atau pembacaan sensor yang dijadikan acuan untuk prosi ini. dalam hal ini data dari pembacaan sensor debit air akan dikirim ke website dengan menerapkan prinsip IoT. Hal ini mendukung kebermanfaatan penerapan metode fuzzy.

Nugroho (2017) terkait penelitian yang berjudul OTOMATISASI PENYIRAMAN TANAMAN DENGAN METODE SAW MENGGUNAKAN ARDUINO BERBASIS WEB dengan menggunakan sensor kelembaban tanah dan sensor suhu untuk memantau kondisi tanaman di rumah, dan melalui dukungan keputusan SAW sistem untuk menentukan metode waktu penyiraman (pembobotan aditif sederhana) untuk menentukan waktu penyiraman berdasarkan pembacaan sensor di pabrik. Adanya sistem ini dapat menghemat air yang digunakan untuk menyiram tanaman, dan tanaman di dalam rumah dapat memenuhi kebutuhan air, sehingga dapat dirasakan manfaat tanaman yang mendukung kegunaan penggunaan pompa air mikro untuk irigasi.

\subsection{IoT (Internet Of Things)}

Internet of Things (IoT) adalah konsep di mana objek dapat mengirimkan data melalui jaringan tanpa interaksi manusia-ke-manusia atau manusiakomputer.

\subsection{Website}

webite adalah kumpulan halaman web yang saling berhubungan dalam domain atau subdomain tertentu. Halaman web ini memberikan informasi yang dapat diakses pengguna melalui server lokal atau server online. Situs web biasanya dibuat untuk memberikan informasi kepada pengguna tentang halhal tertentu, tetapi seiring berjalannya waktu, situs web sekarang juga dapat digunakan untuk situs belanja dan penjualan online, atau bahkan pusat pemantauan berdasarkan alat IoT (Internet of Things).

\subsection{Arduino Uno}

Arduino Uno adalah papan mikrokontroler yang memiliki kontroler tergantung pada spesifikasinya, jenis mikrokontroler akan berbeda-beda. Pada Arduino Uno digunakan mikrokontroler berbasis ATmega328. Ini memiliki 14 pin input dari output digital, 6 di antaranya dapat digunakan sebagai output PWM dan 6 pin input analog, osilator kristal $16 \mathrm{MHz}$, koneksi USB, colokan listrik, konektor ICSP dan tombol reset.

\subsection{Sensor Suhu (DS18B20)}

Sensor Suhu merupakan module untuk mendeteksi Suhu air, yang dapat diakses menggunakan microcontroller seperti arduino, NodeMCU ESP8266. Sensor Suhuair ini dapat dimanfaatkan pada sistem pertanian, perkebunan, maupun sistem hidroponik mnggunakan hidroton.

\subsection{Sensor Keasaman ( $p H m e t e r)$}

Modul sensor merupakan modul untuk mendeteksi pH air, dimana keluarannya berupa tegangan analog. Oleh karena itu, nilai bacaan yang akan dikonversi harus dimasukkan ke dalam rumus di kode program yang dibuat. Karena penggunaan modul sensor pengukur ph, rentang output tegangan analog adalah $0-3 \mathrm{Vdc}$, dan input daya adalah 3,3$5,5 \mathrm{Vdc}$

\subsection{Sensor Kekeruhan Air (Turbidity)}

Sensor kekeruhan analog untuk Arduino merupakan sensor yang mengukur kualitas air dengan mendeteksi kekeruhan. Sensor mendeteksi partikel tersuspensi dalam air dengan mengukur transmisi dan hamburan cahaya yang sebanding dengan tingkat padatan tersuspensi total (TTS). Semakin tinggi level TTS, semakin tinggi kekeruhan air.

\subsection{Pompa Air}

Pompa air adalah alat yang digunakan untuk memindahkan air dari posisi bertekanan rendah ke posisi bertekanan tinggi. Pada dasarnya pompa air biasanya sama dengan motor DC, hanya saja pompa tersebut dikemas agar dapat digunakan di dalam air.

\subsection{Modul Wifi ESP8266}

ESP8266 adalah modul WiFi, yang belakangan ini menjadi semakin populer di kalangan pengembang perangkat keras. Selain harganya yang terjangkau, modul WiFi multi fungsi ini sudah berstatus SoC (System on Chip), jadi ESP8266 bisa kita program secara langsung tanpa perlu mikrokontroler lain. Keuntungan lainnya adalah ESP8266 dapat bertindak sebagai titik akses ad hoc dan klien pada saat yang bersamaan.

\section{METODE PENELITIAN}

Kebutuhan dalam sistem budidaya ikan tombro dengan monitoring Suhu, keasaman air, kekeruhan air ini mencakup dua hal yaitu kebutuhan fungsional dan kebutuhan non fungsional. Berikut ini adalah penjabaran kebutuhan-kebutuhan tersebut.

\subsection{Analisa Kebutuhan Fungsional}

Adapun beberapa kebutuhan fungsional dalam rancang bangun sistem padi aquaponik antara lain :

Tabel 1. Kebutuhan Fungsional

\begin{tabular}{|c|c|c|}
\hline No. & Hardware & Software \\
\hline 1 & Arduino Uno R3 & $\begin{array}{ll}\text { Arduino } & \text { IDE } \\
1.8 .13 & \end{array}$ \\
\hline 2 & Modul ESP8266 & Visual Code \\
\hline 3 & $\begin{array}{ll}\begin{array}{l}\text { Sensor } \\
\text { (DS18B20) }\end{array} & \text { Suhu }\end{array}$ & XАMPP \\
\hline 4 & $\begin{array}{l}\text { Sensor Keasman Air } \\
\text { (pHmeter) }\end{array}$ & Web browser \\
\hline 5 & $\begin{array}{ll}\begin{array}{l}\text { Sensor } \\
\text { (Turbidity) }\end{array} & \text { Kekeruhan } \\
\end{array}$ & - \\
\hline 6 & Pompa Air & - \\
\hline
\end{tabular}




\subsection{Diagram Blok Sistem}

Sistem monitoring dijelaskan Sensor ph dan sensor turbidity yang digunakan untuk mengukur tingkat keasaman dan tingkat kekeruhan air yang terkandung dalam kolam itulah yang akan dikirimkan datanya untuk di monitoring budidaya ikan tombro. Dibantu dengan ESP8266 sebagai penghubung sensor dengan database sehingga data yang keluarkan dapat lancar dan akurat sehingga tidak ada kekeliruan dalam data yang mucul di website pada gambar 1 .

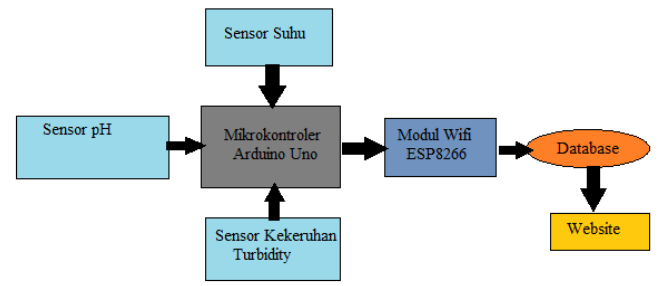

Gambar 1 Diagram blok sistem monitoring pada budidaya ikan tombro

\subsection{Alokasi Pin}

Alokasi pin untuk sistem monitoring sensor dapat dilihat pada Tabel 2, dan pin kontrol aktuator motor servo dapat dilihat pada Tabel 2

Tabel 2. Alokasi pin sistem monitoring

\begin{tabular}{|c|c|c|}
\hline No & Komponen & Pin \\
\hline 1 & Arduino Uno & $\begin{array}{c}\text { Pin Digital dan } \\
\text { Analog }\end{array}$ \\
\hline 2 & Sensor Suhu & $\begin{array}{c}\text { Vcc, Gnd, pin } \\
\text { A2 }\end{array}$ \\
\hline 3 & $\begin{array}{c}\text { Sensor } \\
\text { Keasaman } \\
\text { (pHmeter) }\end{array}$ & $\begin{array}{c}\text { Vcc, Gnd, pin } \\
5\end{array}$ \\
\hline 4 & $\begin{array}{c}\text { Sensor Keruh } \\
\text { (Turbidity) }\end{array}$ & $\begin{array}{c}\text { Vcc, Gnd, pin } \\
\text { A0 }\end{array}$ \\
\hline 5 & ESP8266 & $\begin{array}{c}\text { Vcc(3.3v), } \\
\text { Gnd, pin } \\
3(\text { Rx) }, 4(T x)\end{array}$ \\
\hline 6 & $\begin{array}{c}\text { Mini } \\
\text { waterpump 1 }\end{array}$ & $\begin{array}{c}\text { Vcc, Gnd, pin } \\
9\end{array}$ \\
\hline 7 & $\begin{array}{c}\text { Mini } \\
\text { waterpump 2 }\end{array}$ & $\begin{array}{c}\text { Vcc, Gnd, pin } \\
10\end{array}$ \\
\hline
\end{tabular}

Pada tabel diatas ketiga sensor dan esp8266 memerlukan vcc dan gnd(ground), kemudian serial komunikasi esp8266 dihubungan pada pin 3 dan 4 . Sedangan sensor lembab dihubungan pada pin A2, sensor debit pada pin 5, dan sensor keruh pada pin A0

\subsection{Struktur Menu Website}

Website monitoring pada sistem budidaya ikan tombro terdapat beberapa halaman yaitu halaman utama yaitu halaman home, dan grafik. Berikut stuktur menu pada website dapat dilihat pada gambar 2.

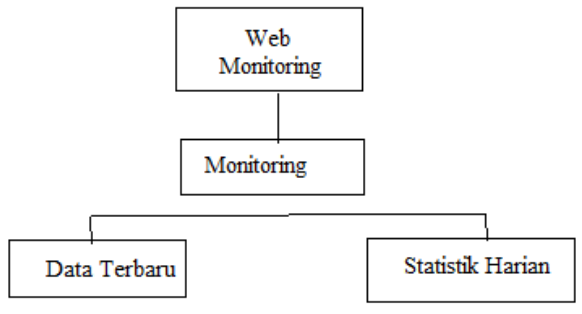

Gambar 2. Struktur menu website

\subsection{Desain Arsitektur Sistem}

Perancangan arsitektur sistem menggambarkan aliran sistem monitoring pada robot. Diagram alir sistem ditunjukkan pada Gambar 3.

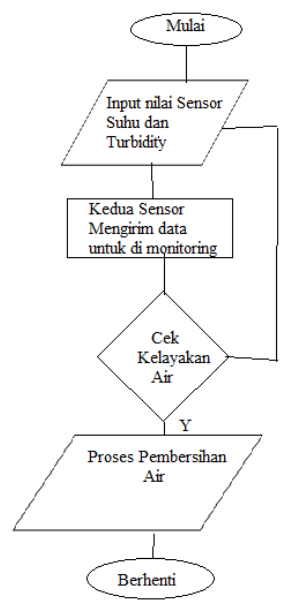

Gambar 3. Flowchart Sistem

\subsection{Perancangan Fuzzy}

Perancangan

sistem

untuk mengimplementasikan metode fuzzy memerlukan beberapa langkah agar dapat menghasilkan keluaran berdasarkan perhitungan fuzzy. Berbagai tahapan proses tersebut meliputi fuzzifikasi, pembuatan basis aturan, penalaran, dan de-fuzzifikasi. Pada metode fuzzy terlihat bahwa proses pada fuzzy control memiliki fungsi untuk menghubungkan ke proses lain, sehingga input yang dihasilkan dapat dihasilkan dari proses sebelumnya hingga keluaran akhir sistem. 


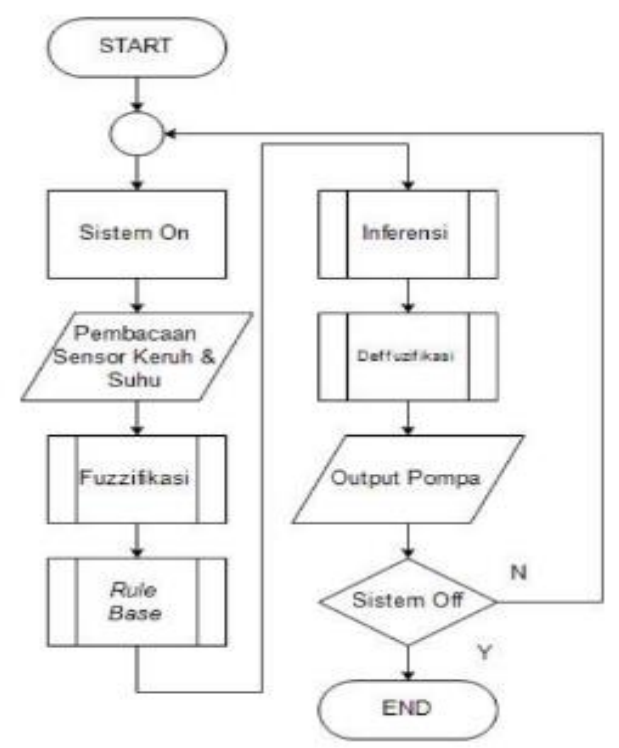

Gambar 4 Perancangan Fuzzy

\subsection{Tahap Fuzzykasi}

Sistem fuzzifikasi akan mengolah 2 masukan yaitu masukan dari sensor suhu dan sensor kekeruhan. Data tersebut mengadopsi nilai eksplisit atau bentuk crip. Fuzzifikasi berubah dari nilai kaku menjadi nilai fungsi keanggotaan Sensor suhu pada fungsi keanggotaan memiliki tiga kondisi yaitu dingin, normal dan panas. Fungsi keanggotaan sensor suhu memiliki 3 kondisi yaitu dingin, normal dan panas. Berikut adalah desain fuzzifikasi temperatur yang diatur pada Gambar 5

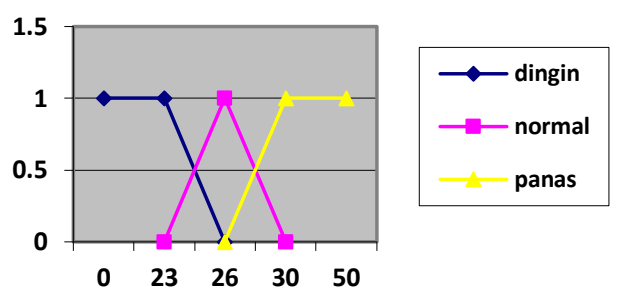

Gambar 5. Fungsi keanggotaan Tidak keruh

$$
\begin{array}{ll}
\mu \text { dingin }(\mathrm{x}) & =1 \text { untuk } \quad \mathrm{x} \leq 23 \\
& =26-\mathrm{x} / 26-23 \text { untuk } 23<\mathrm{x} \\
& =0 \text { untuk } \mathrm{x} \geq 26 \\
& =0 \text { untuk } \mathrm{x} \leq 23 \text { atau } \mathrm{x} \geq 30 \\
& =\mathrm{N}-23 / 26-23 \text { untuk } 23<\mathrm{x} \\
<26 & =1 \text { untuk } \mathrm{x}=26 \\
& =30-\mathrm{x} / 30-26 \text { untuk } 26<\mathrm{x} \\
<30 & =0 \text { untuk } \mathrm{x} \leq 26 \\
\mu \text { Panas (x) } & =\mathrm{x}-26 / 30-26 \text { untuk } 26<\mathrm{x} \\
<30 & =1 \text { untuk } \mathrm{x} \geq 30
\end{array}
$$

Fungsi keanggotaan sensor kekeruhan memiliki 3 kondisi yaitu tidak keruh, keruh dan sangat keruh.
Berikut ini adalah perancangan himpunan fuzzifikasi kekeruhan pada Gambar 6

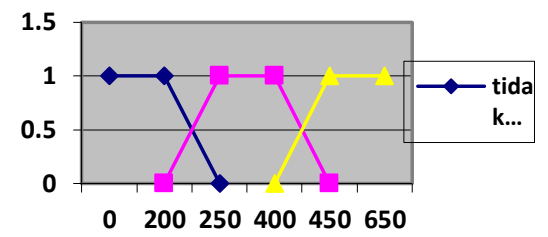

Gambar 6 Fungsi keanggotaan Tidak keruh

$$
\begin{aligned}
& \mu \text { Tidak keruh }(\mathrm{x})=1 \text { untuk } \mathrm{x} \leq 200 \\
& =250-\mathrm{x} / 250-200 \text { untuk } 200< \\
& \mathrm{x}<250 \\
& \mu \operatorname{Keruh}(\mathrm{x}) \quad=0 \text { untuk } \mathrm{x} \leq 200 \text { atau } \mathrm{x} \geq 450 \\
& \mathrm{x}<250 \\
& =\mathrm{x}-200 / 250-200 \text { untuk } 200< \\
& =1 \text { untuk } \mathrm{x}=250 \\
& =450-\mathrm{x} / 450-250 \text { untuk } 250<
\end{aligned}
$$

$\mathrm{x}<450$

$\mu$ Sangat Keruh (x) $=0$ untuk $\mathrm{x} \leq 400$

$$
\begin{array}{ll}
250-200 \text { untuk } 400<\mathrm{x}<450 & =\mathrm{x}-250 / \\
\geq 450 & =1 \text { untuk } \mathrm{x}
\end{array}
$$

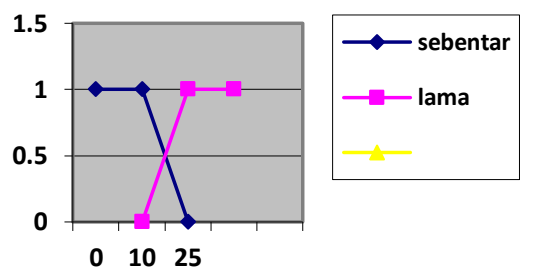

Gambar7 Fungsi keanggotaan Durasi

$$
\begin{array}{r}
\mu \text { Durasi sebentar }(\mathrm{z})=1 \text { untuk } \mathrm{z}=10 \\
=25-\mathrm{z} / 25-10 \text { untuk } 10<\mathrm{x}<25 \\
=0 \text { untuk } \mathrm{z} \geq 25 \\
\begin{array}{r}
\mu \text { Durasi Lama }(\mathrm{z})=0 \text { untuk } \mathrm{z}=10 \\
=\mathrm{z}-10 / 25-10 \text { untuk } 10<\mathrm{x}<25 \\
=1 \text { untuk } \mathrm{z} \geq 25
\end{array}
\end{array}
$$

Tabel 3 Rule Fuzzy

\begin{tabular}{|l|l|l|l|}
\hline No & Suhu & Kekeruhan & Kondisi Pompa \\
\hline 1 & Dingin & Tidak Keruh & Menyala Sebentar \\
\hline 2 & Dingin & Keruh & Menyala Sebentar \\
\hline 3 & Dingin & Sangat Keruh & Menyala Lama \\
\hline 4 & Normal & Tidak Keruh & Mati \\
\hline 5 & Normal & Keruh & Mati \\
\hline 6 & Normal & Sangat Keruh & Menyala Lama \\
\hline 7 & Panas & Tidak Keruh & Menyala Sebentar \\
\hline 8 & Panas & Keruh & Menyala Lama \\
\hline 9 & Panas & Sangat Keruh & Menyala Lama \\
\hline
\end{tabular}

Setelah mendapatkan proses rule base, maka akan menjalankan proses selanjutnya yaitu defuzzifikasi, dimana setiap variabel akan 
mengevaluasi setiap rule untuk mencari nilai minimum.

Tabel 4. Tahap Inferensi

\begin{tabular}{|c|}
\hline $\begin{array}{l}\mathrm{R} 1=\operatorname{Min}(\operatorname{dingin}[25] \& \text { tdk keruh[220]) menyala } \\
\text { sebentar } \\
\quad=\operatorname{Min}(0,33 ; 0,6) \\
\quad=0,33 \\
\quad \text { Nilai z }=0,33=25-\mathrm{z} / 25-10=20,05\end{array}$ \\
\hline $\begin{array}{l}\mathrm{R} 2=\operatorname{Min}(\operatorname{dingin}[25] \& \operatorname{keruh}[220]) \text { menyala } \\
\text { sebentar } \\
\quad=\operatorname{Min}(0,33 ; 0,4) \\
\quad=0,33 \\
\quad \text { Nilai } \mathrm{z}=0,33=25-\mathrm{z} / 25-10=20,05\end{array}$ \\
\hline $\begin{array}{l}\mathrm{R} 3=\operatorname{Min}(\text { dingin }[25] \& \text { sangat keruh }[220]) \\
\text { menyala lama } \\
\quad=\operatorname{Min}(0,33 ; 0) \\
\quad=0 \\
\quad \text { Nilai } \mathrm{z}=0=\mathrm{z}-10 / 10-25=10\end{array}$ \\
\hline $\begin{array}{l}\mathrm{R} 4=\operatorname{Min}(\text { normal}[25] \& \text { tdk keruh[220]) menyala } \\
\text { sebentar } \\
\quad=\operatorname{Min}(0,67 ; 0,6) \\
\quad=0,6 \\
\quad \text { Nilai } \mathrm{z}=0,6=25-\mathrm{z} / 25-10=16\end{array}$ \\
\hline $\begin{array}{l}\mathrm{R} 5=\operatorname{Min}(\text { normal}[25] \& \operatorname{keruh}[220]) \text { menyala } \\
\text { sebentar } \\
\quad=\operatorname{Min}(0,67 ; 0,4) \\
\quad=0,4 \\
\quad \text { Nilai } \mathrm{z}=0,4=25-\mathrm{z} / 25-10=19\end{array}$ \\
\hline $\begin{array}{l}\mathrm{R} 6=\operatorname{Min}(\text { normal }[25] \& \text { sangat keruh[220] }) \\
\text { menyala lama } \\
\quad=\operatorname{Min}(0,67 ; 0) \\
\quad=0 \\
\quad \text { Nilai } \mathrm{z}=0=\mathrm{z}-10 / 10-25=10\end{array}$ \\
\hline $\begin{array}{l}\mathrm{R} 7=\operatorname{Min}(\operatorname{panas}[25] \& \mathrm{tdk} \text { keruh[220]) menyala } \\
\text { sebentar } \\
\quad=\operatorname{Min}(0 ; 0,6) \\
\quad=0 \\
\quad \text { Nilai } \mathrm{z}=0=25-\mathrm{z} / 25-10=25\end{array}$ \\
\hline 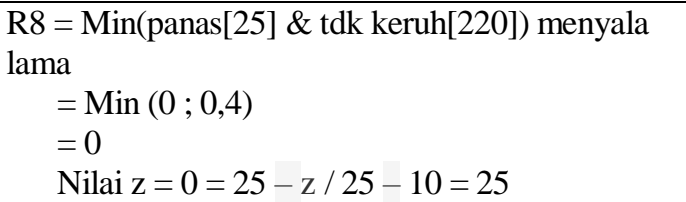 \\
\hline 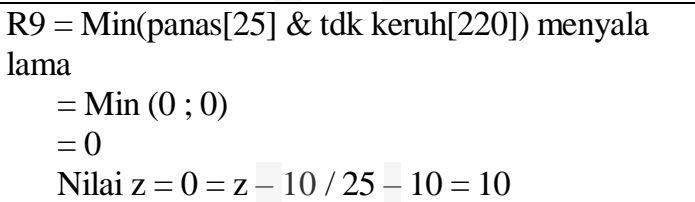 \\
\hline
\end{tabular}

Tabel 3.3 Defuzzykasi

\begin{tabular}{|l|l|l|l|}
\hline Id & L & Z & $1^{*} \mathrm{Z}$ \\
\hline R1 & 0.33 & 20.05 & 6.6165 \\
\hline R2 & 0.33 & 20.05 & 6.6165 \\
\hline R3 & 0 & 10 & 0 \\
\hline R4 & 0.6 & 16 & 9.6 \\
\hline R5 & 0.4 & 19 & 7.6 \\
\hline R6 & 0 & 10 & 0 \\
\hline R7 & 0 & 25 & 0 \\
\hline
\end{tabular}

\begin{tabular}{|l|l|l|l|}
\hline R8 & 0 & 25 & 0 \\
\hline R9 & 0 & 10 & 0 \\
\hline $\begin{array}{l}\text { Juml } \\
\text { ah }\end{array}$ & 1.66 & 155.1 & 30.433 \\
\hline
\end{tabular}

$$
\begin{aligned}
\mathrm{Z} & =\text { jumlah }(1 * \mathrm{z}) / \text { jumlah } 1 \\
& =30.433 / 1.66=18.334
\end{aligned}
$$

\section{HASIL DAN PEMBAHASAN}

\subsection{Implementasi Sistem}

Implementasi sistem merupakan proses pengimplementasian sistem untuk dijadikan sebuah aplikasi. Pada pengujian dijelaskan hasil dari monitoring sistem budidaya ikan tombro. Setelah itu hasil uji coba akan dilakukan analisis untuk mencapai tujuan yang telah dipaparkan sebelumnya.

\subsubsection{Halaman Login}

Pada halaman login diberikan hak akses admin untuk login. Admin harus menginputkan username dan password untuk dapat masuk ke halaman utama admin. Tampilan halaman login dapat ditunjukkan pada Gambar 8

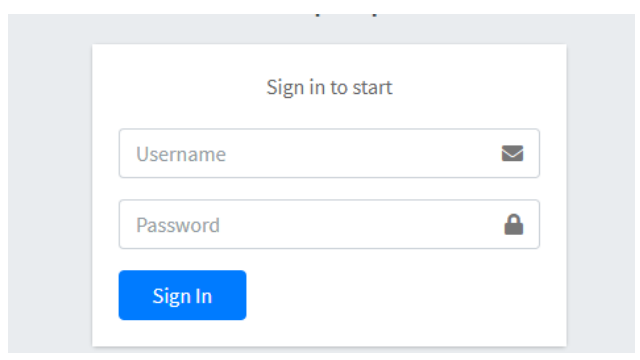

Gambar 8 Halaman Login

\subsubsection{Tampilan Home}

Pada tampilan Hom Web monitoring budidaya ikan tombro dapat menampilkan sensor suhu e website. Berisi informasi monitoring tentang kondisi terakhir dari sistem budidaya ikan tombro yang dideteksi berupa ph air, suhu air, tingkat keruh air kolam (NTU)

\section{MONITORING BUDIDAYA TOMBRO}

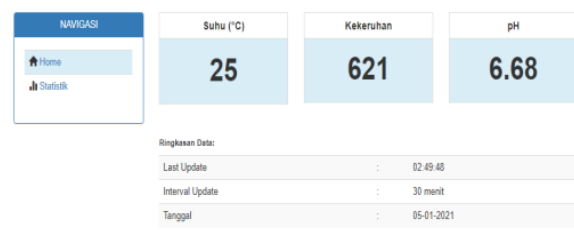

Gambar 9 Halaman Dashboard

\subsubsection{Tampilan Halaman Statistik}

Pada halaman statistik merupakan tampilan dari menu grafik. Berisi grafik dari 3 data sensor yang disimpan pada database 


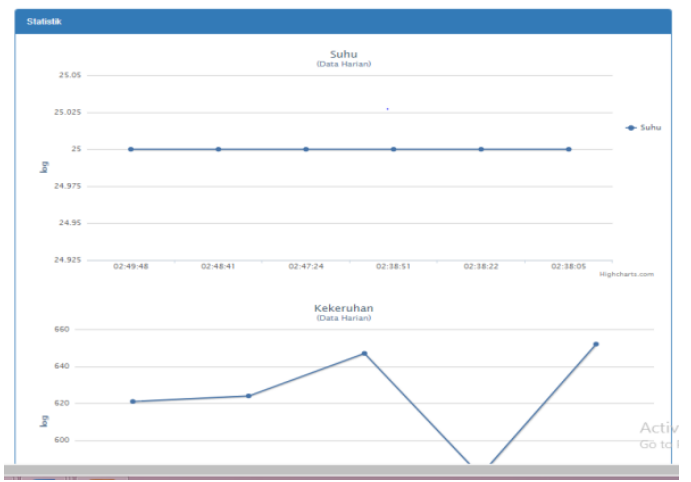

Gambar 10 Halaman Statistik

\subsubsection{Rancang Bangun Prototipe}

Rancang bangun prototype ini merupakan rancangan dari sistem monitoring pada budidaya ikan tombro

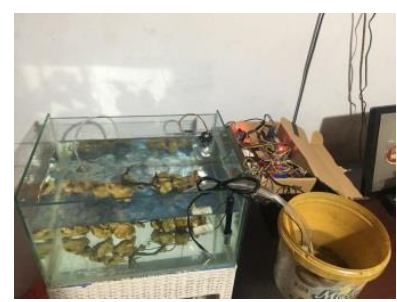

Gambar 11 Tampilan Prototype monitoring

Gambar ini merupakan tampilan prototype dari kolam ikan tombro yang akan digunakan untuk monitoring. Terdapat sensor suhu, sensor $\mathrm{pH}$, sensor kekeruhan air kolam, pompa air kolam.

\subsection{Pengujian ESP8266}

Dilakukan pengujian terhadap ESP8266 yang merupakan modul wifi. Berikut hasil dari pengujian esp8266.

Tabel 5 Pengujian ESP8266

\begin{tabular}{|c|c|c|c|}
\hline \multirow[b]{2}{*}{ No } & \multicolumn{2}{|c|}{ Waktu } & \multirow[b]{2}{*}{$\begin{array}{c}\text { Delay } \\
\text { (Detik) }\end{array}$} \\
\hline & $\begin{array}{c}\text { Waktu } \\
\text { Pengiriman }\end{array}$ & $\begin{array}{c}\text { Waktu } \\
\text { Tampil di } \\
\text { Web }\end{array}$ & \\
\hline 1 & $21: 30: 00$ & $21: 30: 05$ & 5 \\
\hline 2 & $21: 30: 16$ & $21: 30: 21$ & 5 \\
\hline 3 & $21: 30: 33$ & $21: 30: 37$ & 5 \\
\hline 4 & $21: 30: 50$ & $21: 30: 55$ & 5 \\
\hline 5 & $21: 31: 06$ & $21: 31: 11$ & 5 \\
\hline
\end{tabular}

\subsection{Hasil Pengujian sensor suhu DS18B20}

Sensor suhu DS18B20 dapat diuji dengan melihat nilai perbandingan hasil pengukuran suhu antara sensor suhu DS18B20 dengan termometer merkuri.

\begin{tabular}{|c|c|c|c|c|c|}
\hline \multirow[b]{2}{*}{ No } & \multirow[b]{2}{*}{ Waktu } & \multicolumn{2}{|c|}{ Suhu } & \multirow[b]{2}{*}{ Eror } & \multirow[b]{2}{*}{$\begin{array}{c}\text { Keakura } \\
\tan \end{array}$} \\
\hline & & $\begin{array}{c}\text { Sens } \\
\text { or }\end{array}$ & $\begin{array}{l}\text { Termo } \\
\text { meter }\end{array}$ & & \\
\hline 1 & 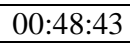 & 24 & 25 & $4 \%$ & $96 \%$ \\
\hline 2 & $01: 19: 05$ & 26,32 & 25 & $5,28 \%$ & $94,72 \%$ \\
\hline 3 & 01:50:08 & 26,56 & 25 & $3,9 \%$ & $96,08 \%$ \\
\hline
\end{tabular}

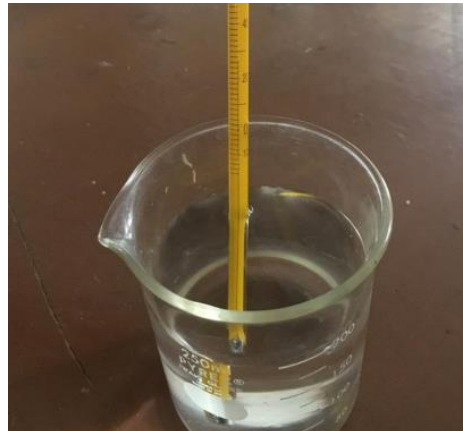

Gambar 12 thermo raksa

\subsection{Hasil Pengujian sensor Turbidity}

Pengujian sensor turbiditas dilakukan dengan melihat nilai perbandingan hasil pengukuran suhu antara sensor turbiditas dengan alat pengukur turbiditas, rentang pembacaan alat ini adalah 0 sampai 1000 .

\begin{tabular}{|c|c|c|c|c|c|}
\hline \multirow{2}{*}{$\begin{array}{c}\text { N } \\
\text { o }\end{array}$} & Waktu & $\begin{array}{c}\text { Sens } \\
\text { or }\end{array}$ & $\begin{array}{c}\text { Turbidity } \\
\text { Meter }\end{array}$ & Eror & $\begin{array}{c}\text { Keakura } \\
\text { tan }\end{array}$ \\
\hline 1 & $00: 48: 43$ & 427 & 389 & $9,76 \%$ & $90,23 \%$ \\
\hline 2 & $01: 19: 05$ & 548 & 517 & $5,99 \%$ & $94,00 \%$ \\
\hline 3 & $01: 50: 08$ & 567 & 531 & $6,77 \%$ & $93,22 \%$ \\
\hline
\end{tabular}

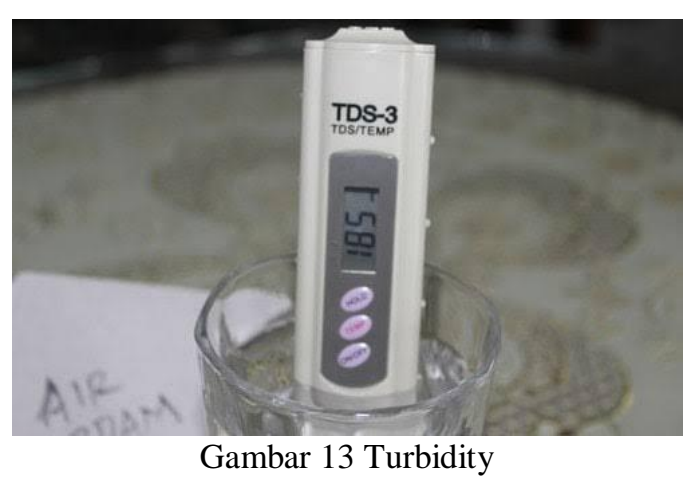

\subsection{Hasil Pengujian sensor $\mathrm{pH}$}

Lakukan uji PH sensor untuk mengetahui apakah sensor ph tersebut aktif sehingga dapat dilakukan proses pendeteksian nilai ph berikut ini hasil pengukuran ph.

\begin{tabular}{|c|c|c|c|c|c|}
\hline \multirow[b]{2}{*}{ No } & \multirow[b]{2}{*}{ Waktu } & \multicolumn{2}{|c|}{ pH } & \multirow[b]{2}{*}{ Eror } & \multirow[b]{2}{*}{$\begin{array}{c}\text { Keakura } \\
\tan \end{array}$} \\
\hline & & Sensor & $\begin{array}{c}\text { pH } \\
\text { Meter }\end{array}$ & & \\
\hline 1 & $00: 48: 43$ & 6,73 & 7 & $3,85 \%$ & $96,15 \%$ \\
\hline 2 & 01:19:05 & 6,8 & 7 & $2,85 \%$ & $97,15 \%$ \\
\hline 3 & 01:50:08 & 6,68 & 7 & $4,57 \%$ & $95,43 \%$ \\
\hline
\end{tabular}




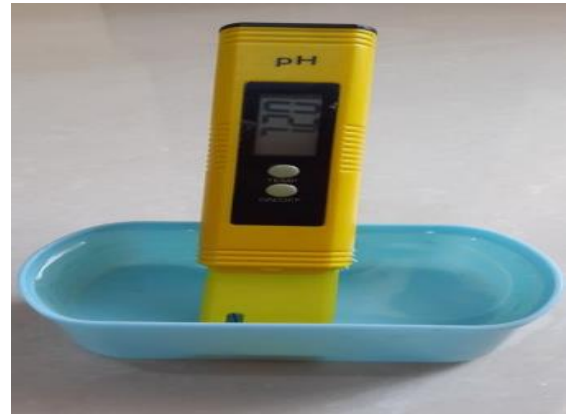

Gambar 14 Pengujian ph

\subsection{Pengujian hasil Fuzzy}

Hasil 6. perhitungan manual

R1 = Min(dingin[25] \& tdk keruh[220]) menyala sebentar

$=\operatorname{Min}(0,33 ; 0,6)$

$=0,33$

Nilai $\mathrm{z}=0,33=25-\mathrm{z} / 25-10=20,05$

R2 = Min(dingin[25] \& keruh[220]) menyala sebentar

$=\operatorname{Min}(0,33 ; 0,4)$

$=0,33$

Nilai $\mathrm{z}=0,33=25-\mathrm{z} / 25-10=20,05$

R3 = Min(dingin[25] \& sangat keruh[220])

menyala lama

$=\operatorname{Min}(0,33 ; 0)$

$=0$

Nilai $\mathrm{z}=0=\mathrm{z}-10 / 10-25=10$

R4 = Min(normal[25] \& tdk keruh[220]) menyala sebentar

$=\operatorname{Min}(0,67 ; 0,6)$

$=0,6$

Nilai $z=0,6=25-z / 25-10=16$

R5 = Min(normal[25] \& keruh[220]) menyala sebentar

$=\operatorname{Min}(0,67 ; 0,4)$

$=0,4$

Nilai $z=0,4=25-z / 25-10=19$

R6 = Min(normal[25] \& sangat keruh[220])

menyala lama

$=\operatorname{Min}(0,67 ; 0)$

$=0$

Nilai $\mathrm{z}=0=\mathrm{z}-10 / 10-25=10$

R7 = Min(panas[25] \& tdk keruh[220]) menyala sebentar

$=\operatorname{Min}(0 ; 0,6)$

$=0$

Nilai $\mathrm{z}=0=25-\mathrm{z} / 25-10=25$

R8 = Min(panas[25] \& tdk keruh[220]) menyala lama

$=\operatorname{Min}(0 ; 0,4)$

$=0$

Nilai $\mathrm{z}=0=25-\mathrm{z} / 25-10=25$

R9 = Min(panas[25] \& tdk keruh[220]) menyala lama

$=\operatorname{Min}(0 ; 0)$

$=0$

Nilai $z=0=z-10 / 25-10=10$
Tabel 7. Defuzzykasi

\begin{tabular}{|l|l|l|l|}
\hline Id & $\mathrm{L}$ & $\mathrm{Z}$ & $1^{*} \mathrm{Z}$ \\
\hline R1 & 0.33 & 20.05 & 6.6165 \\
\hline R2 & 0.33 & 20.05 & 6.6165 \\
\hline R3 & 0 & 10 & 0 \\
\hline R4 & 0.6 & 16 & 9.6 \\
\hline R5 & 0.4 & 19 & 7.6 \\
\hline R6 & 0 & 10 & 0 \\
\hline R7 & 0 & 25 & 0 \\
\hline R8 & 0 & 25 & 0 \\
\hline R9 & 0 & 10 & 0 \\
\hline $\begin{array}{l}\text { Juml } \\
\text { ah }\end{array}$ & 1.66 & 155.1 & 30.433 \\
\hline
\end{tabular}

$$
\begin{aligned}
\mathrm{Z} & =\text { jumlah }\left(1^{*} \mathrm{z}\right) / \text { jumlah } 1 \\
& =30.433 / 1.66=18.334
\end{aligned}
$$

Hasil Perhitungan Alat

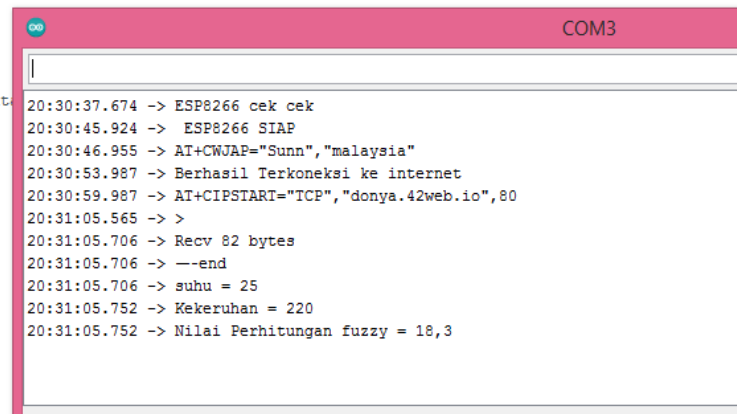

\section{Gambar 15 Perhitungan fuzzy}

\subsection{Pengujian Software Sistem}

Pengujian perangkat lunak dalam penelitian ini dilakukan dengan menguji kesesuaian website dengan web browser. Web browser dirancang untuk mengetahui apakah halaman website yang dibuat dapat menampilkan semua data sesuai dengan desainnya, tidak hanya pada web browser yang sering digunakan Di perangkat. Secara umum. Tabel 8 menunjukkan hasil uji kompatibilitas situs web dengan menggunakan browser web.

Table 8. Pengujian software

\begin{tabular}{|l|l|c|c|c|}
\hline \multirow{2}{*}{ No. } & Aspek Pengujian & \begin{tabular}{c} 
Web Browser \\
\cline { 3 - 5 }
\end{tabular} & $\begin{array}{c}\text { Opera } \\
\text { V1.2.3076 } \\
\text { Choogle } \\
\text { Versi } \\
\text { 87.0.4280 }\end{array}$ & $\begin{array}{c}\text { Microsoft } \\
\text { Edge } \\
\text { Versi } \\
\mathbf{1 1 . 0 . 1 3}\end{array}$ \\
\hline 1. & $\begin{array}{l}\text { Menampilkan } \\
\text { kondisi Suhu Air }\end{array}$ & $\checkmark$ & $\checkmark$ & $\checkmark$ \\
\hline 2. & $\begin{array}{l}\text { Menampilkan } \\
\text { kondisi Keasaman } \\
\text { Air }\end{array}$ & $\checkmark$ & $\checkmark$ & $\checkmark$ \\
\hline 3. & $\begin{array}{l}\text { Menampilkan } \\
\text { kondisi keruh air }\end{array}$ & $\checkmark$ & $\checkmark$ & $\checkmark$ \\
\hline 4. & $\begin{array}{l}\text { Menampilkan data } \\
\text { grafik }\end{array}$ & $\checkmark$ & $\checkmark$ & $\checkmark$ \\
\hline 5. & Fungsi Logout & $\checkmark$ & $\checkmark$ & $\checkmark$ \\
\hline 6. & Tampilan Login & $\checkmark$ & $\checkmark$ & $\checkmark$ \\
\hline
\end{tabular}

Keterangan :

- $\checkmark$ : Berhasil

- $\mathrm{x}$ : Tidak Berhasil 
Terlihat dari hasil pengujian pada Tabel 8 menunjukkan bahwa aplikasi yang dibuat dapat berjalan dengan baik pada web browser Opera, Google Chrome dan Microsoft Edge yaitu tampilan login dan semua fungsi yang ada di halaman muka, seperti panel data atau tabel, Panel data grafik dan fungsi tampilan logout normal, dan semua respons aplikasi dan alat dapat berjalan normal

\section{KESIMPULAN DAN SARAN \\ 5.1 Kesimpulan}

Dari berbagai tahapan pengujian dan perbandingan yang telah dilakukan, diperoleh beberapa kesimpulan, antara lain:

1. Berdasarkan hasil uji fungsi sistem yang telah dilakukan maka dapat disimpulkan bahwa sistem pemantauan penangkaran lumba-lumba dapat bekerja dengan normal.

2. Berdasarkan hasil pengujian pengguna menunjukkan bahwa $53,75 \%$ sangat setuju, $43,75 \%$ setuju, $2,5 \%$ tidak setuju, dan $0 \%$ mengatakan tidak.

3. Berdasarkan hasil pengujian browser bahwa aplikasi yang dibuat dapat berjalan dengan baik pada browser Web Opera versi 61.2.3076, Google Chrome versi 87.0.4280 dan Microsoft Edge versi 11.0.13, semua fungsi yang ada di halaman beranda (seperti panel data atau Tabel), panel data grafis, dan tampilan logout dapat bekerja secara normal, dan semua responsivitas aplikasi dan alat dapat bekerja secara normal.

\subsection{Saran}

Berdasarkan hasil pengujian, dapat dikembangkan website yang lebih baik. Untuk pengembangan selanjutnya, Anda bisa menggunakan platform Android untuk memantau perkembangbiakan lumba-lumba.

\section{DAFTAR PUSTAKA}

[1] Argowindo (2013), "Budidaya Telur Ikan" http://www.agrowindo.com/peluang-usahabudidaya-ikan-tombro-dan-analysisusahanya.htm

[2] Pertanianku, (2016), "Program pembiakan ikan keperawatan", www.pertanianku.com/tata-carabudidaya-ikan-tombro-untuk-pemula

[3] Paktanidigital, (2017), "Tips Sederhana Budidaya Ikan di Tumbro", https://paktanidigital.com/artikel/5-tips-ampangternak-ikan-tombro-bagi-pemula/

[4] Kadir (2019) "Mobile Internet of Things (IoT) untuk pemantauan kualitas air habitat ikan hias di akuarium menggunakan metode logika fuzzy" https://ejournal.itn.ac.id/index.php/jati/article/vi ew/ 1394/1248

[5] Afifuddin (2019) "Penerapan metode fuzzy berbasis ARDUINO dalam pemantauan penggunaan rumah tangga" http://eprints.itn.ac.id/1244/

[6] Nugroho (2017) "Penyiraman Otomatis Menggunakan Metode SAW Arduino Berbasis Web"

http://journals.usm.ac.id/index.php/jprt/article/vi ew/932

[7] Chandra (2014). Sekolah Ilmu Hayati, Universitas Surya. Internet of Things and Embedded Systems in Indonesia, 243-912.

[8] Teknikotomotif.com (2017) "Pompa Air, Fungsi dan Prinsip Kerja" https://www.teknikotomotif.com/2017/04/water-pump-fungsi-dancara-kerjanya.html

[9] Yuliansyah, H. (2016). Jurnal Teknik dan Teknologi Listrik. Gunakan modul ESP8266 berdasarkan arsitektur Istirahat untuk melakukan pengujian kinerja transmisi data nirkabel, Volume 10, Edisi 2

[10] Sebarkan. (13 April 2019). Tutorial untuk mengakses modul sensor $\mathrm{pH}$ meter menggunakan Arduino. https://www.nyebarilmu.com/tutorialmengakses-module-ph-meter-sensormengusing-arduino

[11] Hardy (2018). "Apa itu Hypertext Markup Language (HTML)." Https://www.dictio.id/t/apa-yang-Meaningdengan-hypertext-markup-language-html/15071.

[12] Rajid (Fajar Efendi). (2014). "Bahasa pemrograman populer PHP." Https://www.ubaya.ac.id/2018/content/articles_ detail/144/Bahasa-Pem programming-popularPHP.html

[13] Sinauardino (2016). "ModulwifiESP8622" https://www.sinauarduino.com/artikel/esp8266/

[14] Yassin (24 Juli 2019). Pahami MySQL, fungsinya dan cara kerjanya (lengkap). 